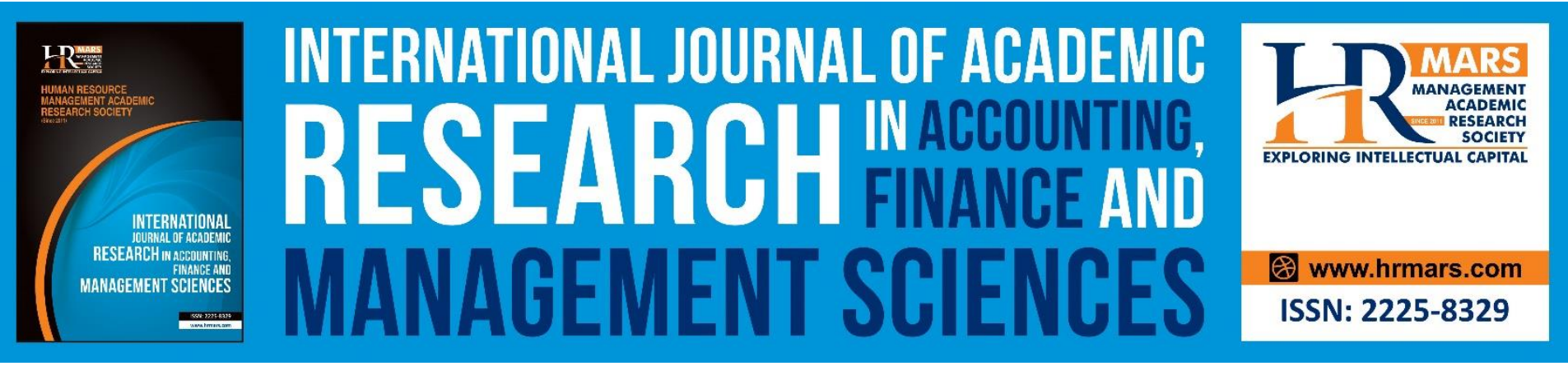

\title{
Ethical Practice Influencers and the uptake of Access to Government Procurement Opportunities program for Youth in Isiolo County, Kenya
}

\author{
Fredrick Ephraim Khaunya Mukabi, Ann Teresa Wanjiru Kangethe, David \\ Newton Simiyu
}

To Link this Article: http://dx.doi.org/10.6007/IJARAFMS/v11-i1/9746

DOI:10.6007/IJARAFMS /v11-i1/9746

Received: 17 January 2021, Revised: 21 February 2021, Accepted: 13 March 2021

Published Online: 29 March 2021

In-Text Citation: (Mukabi et al., 2021)

To Cite this Article: Mukabi, F. E. K., Kangethe, A. T. W., \& Simiyu, D. N. (2021). Ethical Practice Influencers and the uptake of Access to Government Procurement Opportunities program for Youth in Isiolo County, Kenya. International Journal of Academic Research in Accounting Finance and Management Sciences, 11(1), 451475 .

\section{Copyright: (C) 2021 The Author(s)}

Published by Human Resource Management Academic Research Society (www.hrmars.com)

This article is published under the Creative Commons Attribution (CC BY 4.0) license. Anyone may reproduce, distribute, translate and create derivative works of this article (for both commercial and non-commercial purposes), subject to full attribution to the original publication and authors. The full terms of this license may be seen

at: http://creativecommons.org/licences/by/4.0/legalcode

\section{Vol. 11, No. 1, 2021, Pg. 451 - 475}

Full Terms \& Conditions of access and use can be found at http://hrmars.com/index.php/pages/detail/publication-ethics 


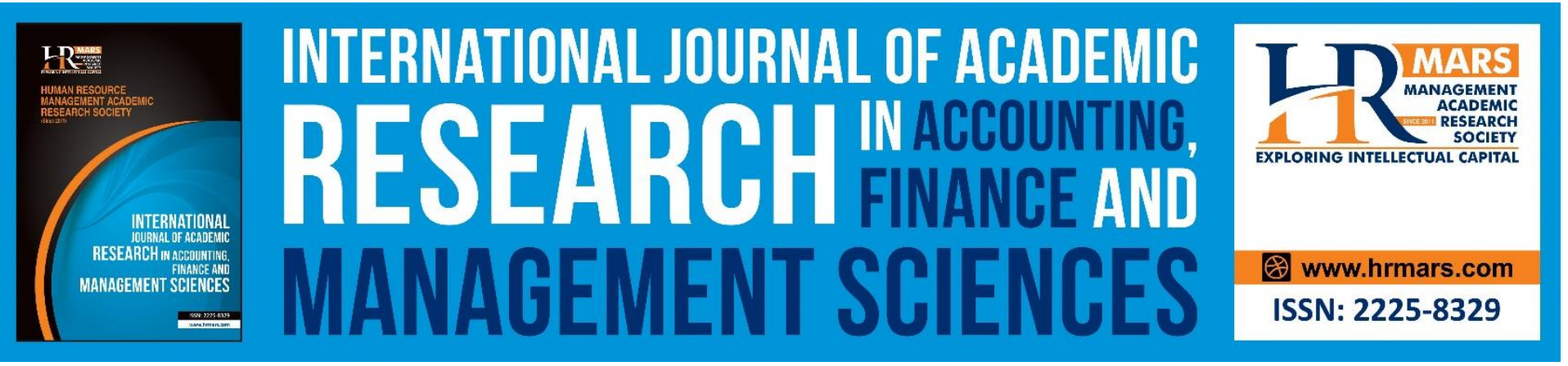

\title{
Ethical Practice Influencers and the uptake of Access to Government Procurement Opportunities program for Youth in Isiolo County, Kenya
}

\author{
Dr. Fredrick Ephraim Khaunya Mukabi, Dr. Ann Teresa Wanjiru \\ Kangethe, David Newton Simiyu \\ Kenya School of Government, Embu Campus \\ Email: fredrick.mukabi@ksg.ac.ke, ann.kangethe@ksg.ac.ke, david.simiyu@ksg.ac.ke
}

\begin{abstract}
Access to Government Procurement Opportunities (AGPO) is an initiative by the Kenyan Government to empower the youth, women and Persons with Disabilities (PWDs) through preferential treatment while seeking Government procurement opportunities. It aims at facilitating enterprises owned by youth, women and PWDs to be able to participate and benefit from thirty percent of the Government tenders. However, considering the numerous challenges experienced by the program, the research investigated the ethical influencers and how they affected uptake of AGPO program. Using the descriptive research design as the study frame, and inferential statistics to establish the Pearson Correlation coefficient to a sample of 55 respondents drawn from the Seven (7) Sub-Counties of Isiolo County in Kenya, the researchers were able to analyze the variables relationship and concluded that ethical had a moderate positive correlation with the uptake of AGPO. It emerged that apart from being aware of ongoing malpractices, these had not discouraged the youth from engaging in AGPO program. The study recommends that there is need for further inquiry to establish the appropriateness of the existing ethical framework governing the AGPO program and appropriateness. This would help guide AGPO policy framework and administration review for effectiveness.
\end{abstract}

Keywords: Ethical, Influencers, Access to Government Procurement Opportunities, Public Procurement, Uptake, and Youth.

\section{Introduction}

Public procurement systems and processes are central to the effectiveness of development expenditure and budgets get translated into services largely through the publics' purchases of goods, services and works according to Mahmood, (2010). According to estimates, $18.42 \%$ of the world's Gross Domestic Product (GDP) is spent through public procurement (Mahmood, 2010).

Public procurement therefore is a key component of a country's public administration that links the financial system with economic and social outcomes in the words of Schapper \& Malta, (2011). It is 
INTERNATIONAL JOURNAL OF ACADEMIC RESEARCH IN ACCOUNTING, FINANCE AND MANAGEMENT SCIENCES

Vol. 11, No. 1, 2021, E-ISSN: 2225-8329 ๑ 2021 HRMARS

therefore seen as an objective and efficient way of setting up a business contract between the state and private entities. It is thus widely used to drive the socio-economic development agenda of a nation, such as an economic development model of preference and reserved groups according to the analysis of Arrowsmith, (2010). Research has shown that the state of public procurement greatly determines the governance and performance of business community performance with public services and cuts across almost every aspect of planning, program management and budgeting. It is therefore deemed an important market in any economy as it consumes a substantial percentage of public revenue of the country (Schapper \& Malta, 2011).

Public procurement is deemed an integral function of governments in both developed and developing countries as the huge financial outflows have a significant impact on their economies necessitating its prudent management. Therefore, prudent handling of public procurement functions is fundamental to achieving economic and socio-political objectives of any government (Thai, 2001). In Australia, resource availability in any procurement process has been adhered to and resources have been availed and the best way to use available assets or resources in the execution of a given project have been determined according to the findings of Schiavo-Campo \& Sundaram, (2000). They opine that this aspect of making resources available has led to increased accessibility of public procurement opportunities by preference and reserved groups in Australia.

In the United States, Procurement professionals have identified and implemented technology that aides the procurement process and supports the entire preferential processes as per the public procurement laws and statutes. In Nigeria, the public procurement has developed policy of stimulating entrepreneurial activities by disadvantaged people owned enterprises (Attaran, 2002).

In Kenya, the Public Procurement and Asset Disposal Act 2015 (GOK, 2015) describes "preference" as the right or opportunity to select tenderers from an identified target group that is considered more desirable than another; and "reservations" as exclusive preference to procure goods, works and services set aside to a defined target groups of tenderers within a specified threshold or region: this group include youths, persons with disability and women for the purposes of Access to Government Procurement Opportunities (GoK, 2015). Therefore, the legal requirement for youth, women, PWDs to access $30 \%$ of AGPO is being implemented within the context of the Access to Government Procurement Opportunities (AGPO) program that was officially launched by the Head of State 2013. This AGPO initiative is founded in the Constitution of Kenya, 2010 Article 227 on the fair equitable, transparent, and cost-effective public procurement of goods and services, and in Article 55 on affirmative action and the Public Procurement and Asset Disposal Act (PPADA), (GOK, 2015). The aim of the program is to facilitate the business enterprises owned by youth, women and PWDs to be able to participate and benefit from Government procuring opportunities. This is to be made possible through the implementation of the legal requirement that $30 \%$ of Government procurement opportunities be set aside specifically for enterprises owned by this category of the working population in business. The program therefore focuses on empowering them by giving them more opportunities to do business with the Government. This aims at ensuring that youths, women, and persons with disabilities are successfully integrated into the economy through procurement to improve Kenya's competitiveness, raise household incomes, reduce poverty, and create a cycle of investment and growth according to Gitari \& Kabare, (2014).

The Government of Kenya through the PPADA in (GOK, 2015) further provides that for the purpose of benefiting from preference and reservations schemes, an enterprise owned by Kenyan youth, women or PWDs shall be a legal entity that is registered with the relevant Government body 
INTERNATIONAL JOURNAL OF ACADEMIC RESEARCH IN ACCOUNTING, FINANCE AND

MANAGEMENT SCIENCES

Vol. 11, No. 1, 2021, E-ISSN: 2225-8329 @ 2021 HRMARS

and has at least seventy percent membership of youth, PWDs and the leadership shall be one hundred percent youth, PWDs, respectively.

\section{Ethical Practices and Public Procurement}

Worldwide, public procurement attracts a lot of attention and in the words of Callendar \& Mathews, (2000), this is often because of its size. Most developed countries spend an average of $20 \%$ of their Gross Domestic Product (GDP) on public procurement while developing nations spend up at a tune of roughly $50 \%$ of their GDP on this process. This scenario therefore predisposes the process to a myriad of challenges that could be legal, regulatory, and ethical according to Mukabi, Kangethe and Simiyu, (2020). Various countries therefore have instituted procurement reforms aimed at reinvigorating ethical considerations in the procurement processes through enactment of laws and development of regulations. The objective is to infuse these reforms in the process to ensure compliance to procurement ethical standards. De Boer and Telgen (1998) reiterate that compliance to procurement ethical issues positively affects not only the developing world but also countries with developed economies. This position is further reinforced by the findings of Gelderman, Ghijsen and Brugman (2006) who argue that compliance in public procurement is of great importance in any procurement function and ethical practices must take prominence.

According to, Public procurement in Kenya plays a significant role in the utilization of public resources and realization of the economic development agenda (Amemba et al., 2013). In 2013, the Republic of Kenya enforced procurement regulations which began the Access to Government Procurement Opportunities (AGPO) program, under the National Treasury Public Procurement Directorate. Preference and reserved and other marginalized groups could procure $30 \%$ of public goods and services in line with Article2 of the PPDR of 2013 and Article 27 of the Constitution of Kenya, 2010, on equality and freedom from discrimination (Wazir \& Achuora, 2020). The primary objective of the AGPO initiative was to ensure that preference is made reserved for discriminated groups to actively participate in public procurement. The benefits of being AGPO registered include: the ability to participate in $30 \%$ of public tenders; being able to qualify for Local Purchase/Service Orders financing from the Youth/PWDs Enterprise Development Fund; exclusion from bid bonds; and invoice discounting with financial institutions (Wazir \& Achuora, 2020).

The Government went further to ground the program in law which requires all public entities to reserve thirty percent (30\%) of their total procurement budget to preference and reserved groups (women, youths and persons living with disabilities), PPADA, 2015, section 157 (5).The AGPO agenda is to bring the preference and reserved groups (women, youth and people living with disabilities) into the country's socio-economic development framework to help catalyzes the realization of the Kenya Vision 2030, the country development road map (GoK, 2013) and help realize the United Nations Millennium Develop

\section{Problem Statement}

The AGPO initiative by the GOK through the National Treasury aimed at facilitating the businesses registered by youth, women and PWDs to be able to access, participate and benefit from the various Government procuring opportunities. This was to be made possible by the implementing the legal provisions in the Constitution of Kenya 2010 Article 227 and which were to be realized through the Public Procurement and Asset Disposal Act (PPADA), 2015 which stipulates that 30\% of all Government procurement opportunities be set aside specifically for enterprises owned by these 
INTERNATIONAL JOURNAL OF ACADEMIC RESEARCH IN ACCOUNTING, FINANCE AND MANAGEMENT SCIENCES

Vol. 11, No. 1, 2021, E-ISSN: 2225-8329 @ 2021 HRMARS

cadres of suppliers. The Cabinet Secretary for National Treasury had earlier facilitated this by publishing the Public Procurement Preference and Reservations (Amendment) Regulations, 2013 (GOK, 2013) which aimed at supporting the special interest groups through Access to Government Procurement Opportunities (AGPO) program (GOK, 2013).

In the context of AGPO however, it is important to note that appreciating ethics and practicing good ethical behaviour are key aspects in the procurement and supply profession, and the procurement professional should always disclose any potential conflict of interest and follow the advice given from a person in authority. The case in Kenya on ethical practices and procurement therefore requires further investigation. A study conducted by Sengbeh, (2015) to evaluate ethical procurement practices and supply chain performance of the Kenyan energy sector concluded that supply chain performance is influenced by accountability practices in procurement and that integrity practices in procurement should be adopted in the energy firms to ensure supply chain performance. Ndolo and Njagi, (2019) in their study on the role of ethics in procurement process effectiveness in water sector (EWASCO) in Embu County, Kenya concluded that there is need to establish training programs for procurement staff along ethical issues as well as maintaining high organizational culture through strong codes of ethics.

These studies however fail to relate the influence of ethical practices to the uptake and effectiveness of the AGPO initiative by the youth considering that ethical issues play a pivotal role in procurement decisions across all procuring agencies and institutions. The case of Isiolo is also unique considering that there are no earlier studies of this nature in the region, and this will help open up some understanding of the dynamics of the AGPO laws and regulations in their application within the ethical framework of its implementation.

The paper therefore seeks to establish whether the AGPO process in Isiolo County, Kenya is operated within the existing ethical frameworks of professional code of conduct; objective procurement evaluation criteria; and compliance of the public service constitutional provisions of ethics and integrity and how this influence effectiveness of this procurement process.

\section{Theoretical Framework}

The study is conceptualized and based on the following theoretical approaches:

\section{Preferential Procurement Model}

According to this model, procurement may be used to support socio-economic policies using various approaches. These are preferencing, reservations, indirect strategies, and supply-side measures. A preferential procurement policy is one that promotes objectives additional to the ones associated with the immediate goal of the study itself (Simayi, 2005). Procurement has been used internationally to support several socio-economic and even political objectives. Developed economies like the United States of America use reservation schemes and supply-side schemes to ensure a market share of small business enterprises and minority business enterprises are enhanced and upheld. Under the generic schemes of preferential procurement, this reservation scheme encompasses booking of contracts to suppliers who meet certain qualifications, for instance firms or contractors owned, managed and controlled by a target group population, are classified as being small enterprises, have equity ownership by companies with prescribed features and or are joint venture between targeted and non-targeted groups (Arrowsmith, 2010). Even when all contractors qualified to undertake the contract are eligible for consideration to tender, tender evaluation points 
INTERNATIONAL JOURNAL OF ACADEMIC RESEARCH IN ACCOUNTING, FINANCE AND MANAGEMENT SCIENCES

Vol. 11, No. 1, 2021, E-ISSN: 2225-8329 @ 2021 HRMARS

are granted to those contractors who fulfil recommended criteria or who undertake to attain specific goals in the performance of the contract according to a study by Wanderi, (2014).

For the generic of indirect schemes, procurement strategies and requirements are used to promote policy objectives by limiting the way the procurement is delivered. Specifications of the indirect scheme require that the contractor undertakes work that is related with the contract and is beneficial to the society and general growth of the economy like provision of education bursaries and provision of community centers (Roodhooft \& Abbele, 2006). For the supply side generic, measures are provided to targeted enterprises to overcome barriers to competing for tenders or for participating in procurement within the supply chain for instance facilitation to access to finance or securities, mentorship, and capacitating workshops among other (Arrowswith, 2010).

The broad AGPO initiative in Kenya herein under study embraces the Preferential Procurement Model since there is selective treatment over the government procurement opportunities towards the youth, women, and persons with disabilities to cushion them against established and highly competitive bidders.

\section{Teleological Ethical Theories}

These are theories that are concerned with the consequences of actions which means the basic standards for our actions being morally right or wrong depends on the good or evil generated. There are three teleological ethical theories namely ethical egoism, utilitarianism and eudaimonism.

\section{Ethical Egoism}

The ethical egoism theory that posits that an action is good if it produces or is likely to produce results that maximize the person's self-interest as defined by them, even at the expense of others Baumane-Vitolinaa, Calsa and Sumilos, (2015). The theory is based on the notion that it is always moral to promote one's own good, but at times avoiding the personal interest could be a moral action too. This makes the ethical egoism different from the psychological egoism which holds that people are self-centred and self-motivated and perform actions only with the intention to maximize their personal interest without helping others, thereby denying the reality of true altruism meaning sacrificing one's personal interest in the welfare of others.

\section{Utilitarianism}

The Utilitarianism theory holds that an action is good if it results in maximum satisfaction for many people who are likely to get affected by the action. For example, if a manager creates an annual employee vacation schedule after soliciting the vacation time preferences from all the employees and then go ahead and honour their preferences, then he would be acting in a way that would in turn maximize the satisfaction of all the employees.

\section{Eudaimonism}

Eudaimonism is a teleological theory which posits, that an action is good if it results in the fulfillment of goals along with the welfare of the human beings. The actions are said to be fruitful if it promotes the fulfillment of goals constitutive of human nature and its happiness. A good example is if manager enforces employee training and knowledge standards at work. These are natural components of human happiness since they result in the fulfillment of both the goals and welfare of 
INTERNATIONAL JOURNAL OF ACADEMIC RESEARCH IN ACCOUNTING, FINANCE AND

MANAGEMENT SCIENCES

Vol. 11, No. 1, 2021, E-ISSN: 2225-8329 @ 2021 HRMARS

the employees. Therefore, the rightness or wrongness of any actions depends on the kind of consequences.

Based on these Teleological theories, the actions of agents, who are the government officers responsible for the administration of AGPO are guided by decisions based on whether the outcomes of the decisions will be acceptable based on the moral fibre of society, the existing laws and regulations such as the PPADA and KISM in the procurement practice. The consequences therefore determine the actions. The moral and ethical considerations therefore become key in decision making based on the possible consequences.

\section{Deontological Theories}

As described by Kant (1785), Kantian Ethics Deontological theories of ethics differ from the teleological theories of ethics based on the perceived positive consequences which may be good even when the actions are bad. According to these theories therefore, although the consequences of an act is good, some acts towards realizing these positive consequences are always wrong. Therefore, in deontological theories actions are judged as ethical or unethical based on duty or the intentions of an actor. Kant's ethical theory includes duty for the sake of duty without regard to human happiness. He describes duty as "the action which is objectively practical according to this law and duty.

The Deontological approach is practiced by procuring entities that follow legal and generally accepted moral norms. They tend to follow codes of ethics and try to avoid. The establishment of laws to guide the AGPO initiative alongside the existing standards of ethical practice for PSCM practitioners by KISM is supported by the Deontological theories as it provides a basis for providing the legal framework to be adhered to alongside the moral norms that govern the practice.

\section{Ethical Paths}

The discussed ethical theories are summarized and described as the mountain ethical paths by Traer, (2013) when he illustrates the task of understanding normative ethical traditions. He notes that when people use the words 'duty' and 'rights', they are referring (consciously or otherwise) to theories that are concerned with right action. If, on the other hand, they are discussing our ethics in terms of our 'character' or 'relationships', then they are referring to theories of being good. 'Right action' and 'being good' identify different paths on the mountain. This is illustrated in Figure 1, you can see that ethical theories emphasizing duty or rights branch off the right action path, whereas ethical theories concerning character or relationships diverge from the being good path. 
INTERNATIONAL JOURNAL OF ACADEMIC RESEARCH IN ACCOUNTING, FINANCE AND MANAGEMENT SCIENCES

Vol. 11, No. 1, 2021, E-ISSN: 2225-8329 @ 2021 HRMARS

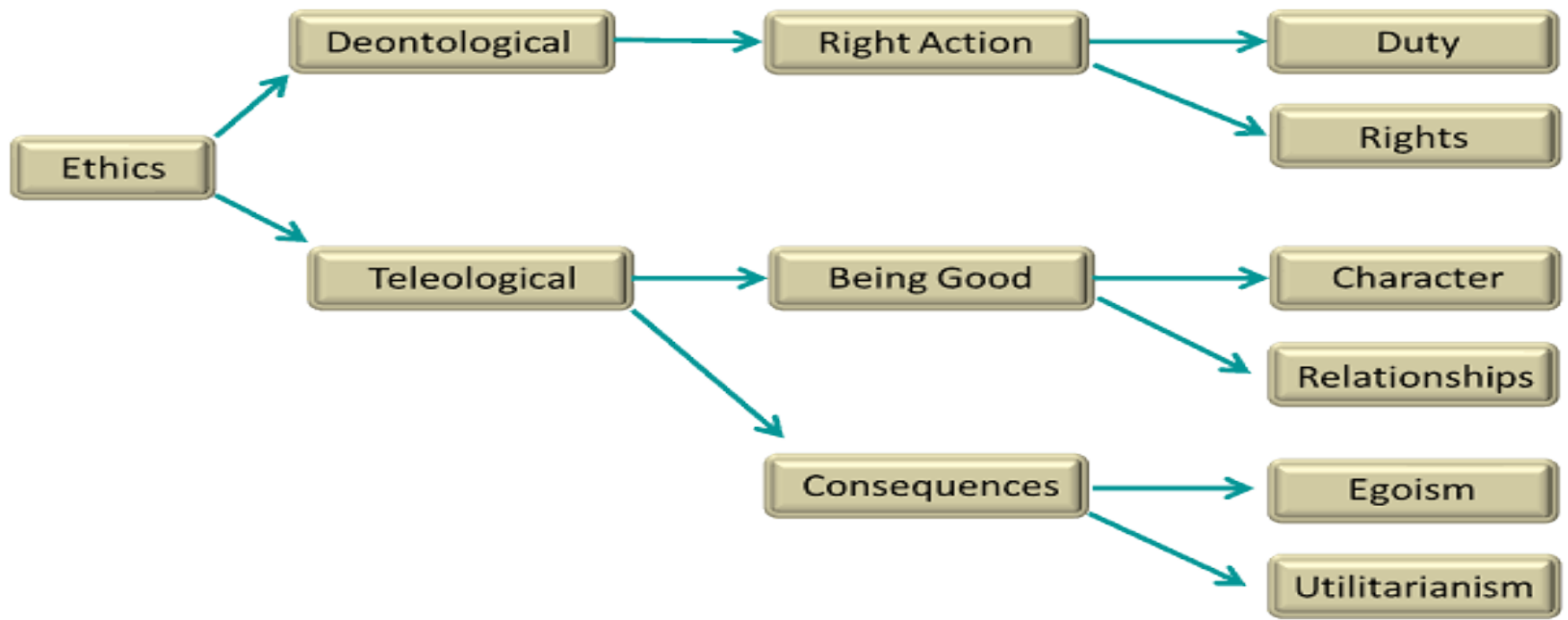

Figure 1. Ethical Paths

Source: Adapted from Traer, (2013)

\section{Conceptual Framework}

The researchers conceptualized that Ethical practices through professional code of conduct, objective procurement evaluation criteria and compliance of the public service constitutional provisions of ethics and integrity and how they influence the uptake of AGPO. The relationship is shown in Figure 2.

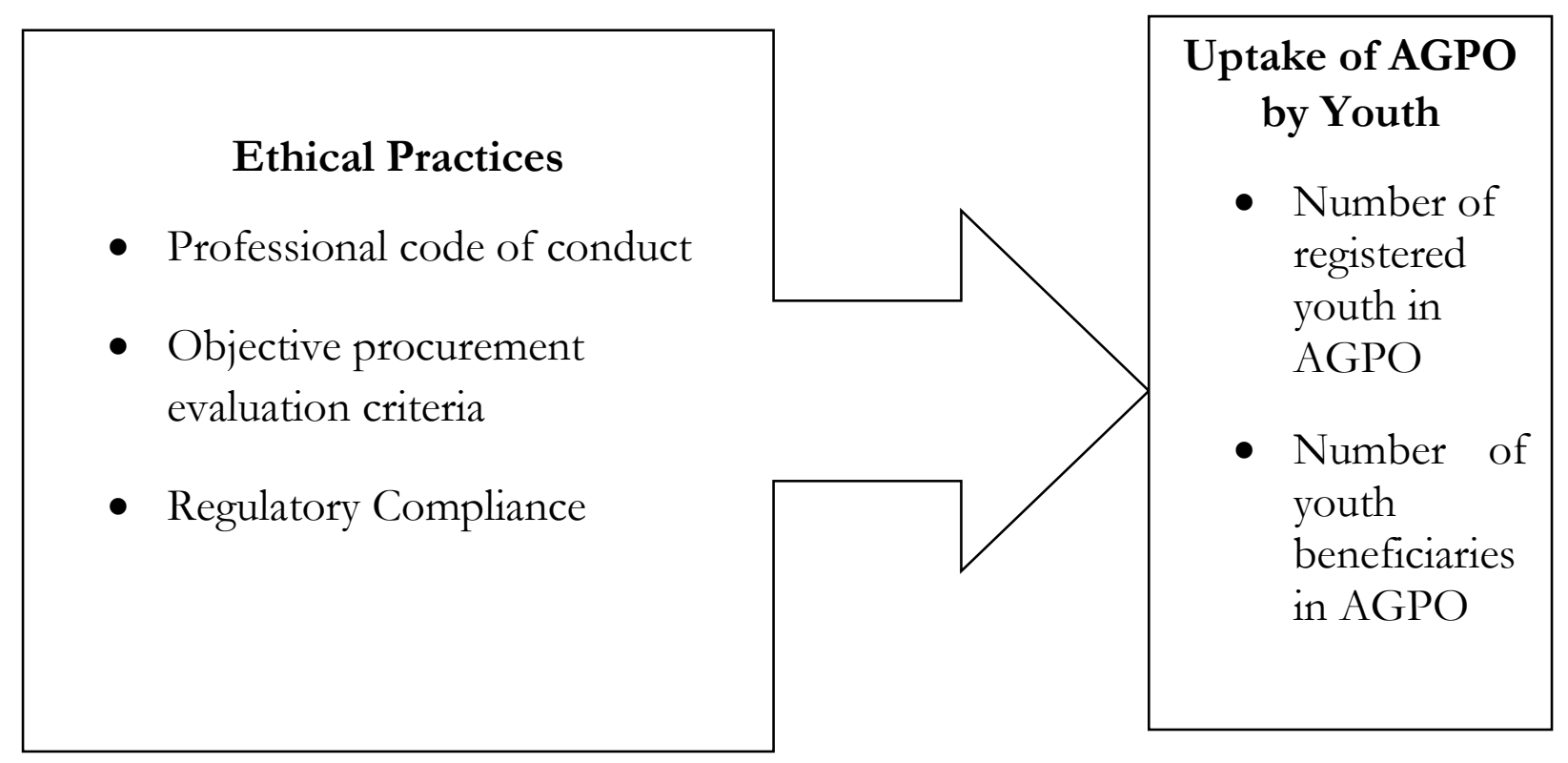

Figure 2. Conceptual Model

(Source: Authors. 2021)

The United Kingdom's Chartered Institute of Procurement and Supply (CIPS) summarizes ethical practices for its professionals by highlighting the following aspects of ethical behavior: the 
INTERNATIONAL JOURNAL OF ACADEMIC RESEARCH IN ACCOUNTING, FINANCE AND MANAGEMENT SCIENCES

Vol. 11, No. 1, 2021, E-ISSN: 2225-8329 @ 2021 HRMARS

officers not engaging in conduct, either professional or personal, which would bring the procurement profession into disrepute; officers not accepting inducements or gifts other than any declared gifts of nominal value which have been sanctioned by your employer; not allowing offers with vested interests to influence, or be perceived to influence, your business decisions; and being aware that the officers' behaviour outside their professional life may influence how they are perceived as professionals.

In Kenya, ethical practices by officers charged with the administration of the AGPO initiative like any other Procurement and Supply Chain Management (PSCM) process are in part contained and summarized within the draft document on the Code of Ethics and Standards of Professional Conduct of Kenya Institute of Supplies Management (KISM).

\section{Review of Literature}

Governments the world over have incorporated ethical behavior as an integral feature of the societies they govern. The application of ethical practices objectives through public procurement has developed over years after extensive research (Callerstig, 2014). There are also plans of increasing the effectiveness, efficiency and transparency of procurement systems to ensure that the disadvantaged people are put into consideration. In South Africa, preferential treatment is given to the blacks to accommodate group differences, encompass the right to reparation for past inequalities and to uplift vulnerable groups in society (Wazir \& Achuora, 2020). This has been made possible by availing resources, making information available and better technological devices. Similarly, in Malawi, a reservation scheme is currently being applied to the ICT sector for procurement below BWP 300,000 (US\$ 46,000), where the opportunity to bid is reserved for $100 \%$ citizen-owned companies (Kennekae, 2010).

The Chairman, Ethics and Anti-Corruption Commission of Kenya, Phillip Kinisu in his address on the Kenyan State of Ethical Practices in May 2019 observes that the absence of ethical conduct would obviously jeopardize the authority of the state by inculcating lawlessness and ultimately 'failed state' status of such a nation. Studies have shown that where ethics in public service are weak, corruption, unethical conduct, inefficiency, poor services and general poverty of the citizenry abound. There has been established a strong correlation between public service management systems founded on strong ethical standards and prosperity of nations according to an Ethics and AntiCorruption Report (GOK, 2018) and the emergence of the East Asian Tigers corroborates this.

In the developed countries, societies, there is general intolerance for unethical conduct and its rewards due to effective systems for enforcing such ethical conduct within public service.

Ethics is discussed as being primarily concerned with issues such as bribes and confidentiality (Kenneth, 1989). According to him, ethics involves the philosophical study of morality as guide by internal conviction against what is wrong and right. Since in all government activities, public procurement is most vulnerable to corruption and fraudulent practice, according to the Economic Recovery Strategy for Wealth and Employment Creation, (ERSWEC, 2003), it becomes very important that the public procurement function is discharged with probity, transparency and accountability in a manner that secures best value for public money, (PPADA, 2005).

\section{Professional Code of Conduct}

Codes of behavior are designed to anticipate and prevent certain specific types of behavior, for example conflict of interest, self-dealing, bribery, and inappropriate actions. Although codes of 
INTERNATIONAL JOURNAL OF ACADEMIC RESEARCH IN ACCOUNTING, FINANCE AND MANAGEMENT SCIENCES

Vol. 11, No. 1, 2021, E-ISSN: 2225-8329 @ 2021 HRMARS

conduct can be brief, most often they are lengthy and detailed. This is because this detailed scope is necessary to both protect the employee while at the same time protecting the reputation of the government. Most codes of conduct focus on the "do nots" rather than on affirmative obligations. They detail specific actions in which employees are not to engage (Gilman, 2005).

Globally, governments and procurement departments are faced with challenges in delivering quality products and services, including challenges of increasing debt and budget cuts, (American City \& County, 2012). In some cases, integrity of the process exuberates the problem, and this notwithstanding good practices do exist, despite the reports of wastage and inefficiency. These good results being realized are based on best practice principles which are now being adapted. The consolidation and sharing of these best practices with those responsible for procurement in the public sector could have a significant effect on ethical procurement practices.

The National Institute of Governmental Purchasing (NIGP) and the United Kingdom's Chartered Institute of Purchasing and Supply (CIPS) collaborated and jointly unveiled Ten Global Public Procurement Practices. This is part of a larger shared initiative to define and formalize global professional standards for government procurement officials. These ten standard practices provide guidance across a set of procurement activities namely: Strategic Procurement Planning; Performance Measurement; Performance Metrics; Use of Cooperative Contracts; Transparency; Risk Management; Ethical Procurement; Procurement Policy Manual; Performance Management; and Performance-Based Contracting, (American City \& County, 2012).

All public entities at different levels of government perform similar procurement activities, as much as the approaches and outcomes vary due to each entity's practices arising from their unique operating environments. Therefore, creating formal standards of procurement practice as reference points, through this collaboration of public sector professionals around the world, provides agencies an authoritative source to define professional standards of practice across critical public procurement functions.

Due to increased demand in ethical governance and public pressure for fiscal responsibility, procurement professionals need to ensure that they maximize the value of every expenditure. For example, U.S. the government spends a combined seven trillion dollars, Canadian government 360 billion dollars, and U.K. government more than 500 billion pounds. Therefore, consistent and professional procurement practices across governments could positively impact the effective expenditure of public funds, (American City \& County, 2012)

The Kenya Institute of Supplies Management (KISM) has developed a draft of a Code of Ethics and Standards for Professional Conduct which provides guidance and sets common ethical standards to assist procurement professionals to deal with the ethical dilemmas they face in the course of their duties. The standards of professional conduct offer consistency in professional behavior and increase awareness of best practices and excellence that should be incorporated in procurement and supply chain activities (GOK, 2020).

The works of Ndolo and Njagi, (2018) on the Role of Ethics in Procurement Process Effectiveness in the Water Sector in Kenya in which they focused on Embu Water and Sewerage Company (EWASCO) in Embu County confirmed the need to establish training programs as well as maintaining high organizational culture through strong codes of ethics. The need to distribute and train staff in the Agency on the Public Procurement and Disposal Act (2015), policies and procedures was found urgent and necessary. 
INTERNATIONAL JOURNAL OF ACADEMIC RESEARCH IN ACCOUNTING, FINANCE AND MANAGEMENT SCIENCES

Vol. 11, No. 1, 2021, E-ISSN: $2225-8329$ @ 2021 HRMARS

\section{Objective Procurement Evaluation Criteria}

An important objective of public procurement practice and procurement regulation is to ensure integrity in the system. This means that procurement should be carried out without any influence of corruption. Corruption can cover various types of practice, according to Sacconi, (2010) and many such practices involve forms of collusion between government and bidders, notably in awarding contracts because of bribes; to firms in which one has a personal interest; to firms in which one's friends, family or business acquaintances have an interest; and for political expediency. This type of corruption may occur in the execution as well as award of contracts for example when officials collude with bidders to allow them to claim extra payments for non-existent work, (Parsons, 2011).

Objective procurement evaluation starts with the procurement staff following an ethical code which dictates their behaviour and actions while conducting business. Walker, \& Sidwell, (2006), posits that ethical procurement practices should be extended to all stakeholders in the procurement cycle. Objective procurement evaluation should also include an understanding of suppliers' operations and the procurement professional should offer guidance and support when improvement is necessary or appropriate in this process without bias. Public procurement procedures are therefore expected to be transparent and able to promote fair and equal treatment for bidders. This is because public resources linked to public procurement need to be used in accordance with intended purposes.

The United Nations Commission on International Trade Law (UNCITRAL) for example guides on request for proposals and provides for use of the kind of two-envelope procedure found also in the principal method for procurement of services in the selection procedure with simultaneous negotiations (Article 43 of the Model Law), according to Robert, (2008). Hence, for the purpose of evaluating the final proposals, Article 48(3) of UNICITRAL guides that the effectiveness of the proposal is to be evaluated separately from the price, and that the price is to be considered only after the completion of the evaluation. The reasons for such a two-envelope procedure are the same as with the principal method for procurement of services, namely, to ensure that appropriate weight is given to the different criteria and to prevent the deliberate abuse of discretion.

Earlier research by Sengbeh, (2015) on Ethical procurement practices and supply chain performance of Kenyan Energy Sector established that supply chain performance is influenced by accountability practices in procurement and recommended that the integrity practices in procurement should hence be adopted in the energy firms to ensure supply chain performance.

\section{Public Procurement Regulatory Compliance}

Regulatory compliance is the organizations' adherence to laws, regulations, guidelines and procedures relevant to its business practice, (Payan \& McFarland, 2005; Gelderman.et.al, 2006). Whereas compliance is the degree to which an agent adheres to principal's directives, policies and procedures, non-compliance is the degree to which such an agent initiates deviant policies and procedures that are not approved by the principal in the words of Roodhooft and Abbeele, (2006). Therefore, regulatory compliance is at the core of ethical practices in any organizational operations.

Public procurement regulatory compliance therefore is the procurement entities' adherence to laws, regulations, guidelines and procedures that apply to procurement practice in the relevant country or state. The Kenya National Audit Office and the Internal Auditor General (IAG) alongside Public Procurement Oversight Authority (PPOA) and the KISM work closely in ensuring regulatory compliance through transparency and adherence to procurement laws and regulations in Kenya. The exact scope of oversight generally includes the legality, transparency and efficiency of procurement, 
INTERNATIONAL JOURNAL OF ACADEMIC RESEARCH IN ACCOUNTING, FINANCE AND MANAGEMENT SCIENCES

Vol. 11, No. 1, 2021, E-ISSN: 2225-8329 @ 2021 HRMARS

according to the PPOA report, (GOK, 2004). Although the main objective of this oversight mechanism is ultimately to prevent and deter corrupt practices in procurement, it can bring a much wider range of benefits, such as increased transparency and accountability, enhanced trust in authorities and government contracting, contributing to a good reputation among contracting authorities, saving costs and improving competition, (GOK, 2014).

PPOA is the main procurement oversight body in Kenya whose mandate is to conduct investigations on any complains of noncompliance with the procurement rules and regulations and makes recommendation to the Ethics and Anti-Corruption Commission (EACC), according to the PPOA guidelines, (GOK, 2010). This is a legal entity established under the Constitution of Kenya 2010 to support the enforcement of compliance with the procurement laws and regulations by investigating and recommending prosecution of suppliers and or procurement or public officers found to have acted corruptly in the public procurement process and therefore culpable and the Public Procurement Oversight Authority (PPOA) is critical in playing this role, (GOK, 2010).

However, according to Panya \& Were, (2018) on their study of Homa Bay County, Kenya, issues of non-compliance are reported frequently by the agencies tasked to oversee the practice. For instance, in the period ending 30 June 2014, data from the office of the Auditor-General reports various issues of non-compliance ranging from non-conformity to procurement regulations to sheer impunity towards the PPDA Act, 2015 within the County Government of Homabay. According to the Auditor Generals' report, payments were made to various firms for provision of legal services, insurance services and conducting of a baseline survey, where no procurement procedure was followed and documents confirming the provisions of the services were not availed for audit review as per the Auditors Generals report, (GOK, 2014).

Recent studies on this selective preferential procurement treatment in Kenya through the AGPO initiative's uptake have revealed that the legal and regulatory framework in some instances have an insignificant influence on the uptake of the program (Mukabi, Kangethe \& Simiyu, 2020). This was partly attributed to the long bureaucratic processes involved in acquisition of the multiple licences needed by start-ups that wish to participate in the AGPO program. The AGPO initiative like any other procurement process is susceptible to non-compliance by the agents and hence the need for full enforcement of compliance by these agencies. Studies by Wazir \& Achuora, (2020) on factors affecting access to government procurement opportunities (AGPO) by preference and reserved groups in Nairobi City County, Kenya found that resource availability, level of information, procurement ethical issues and technical capability had a positive significant influence on access to government procurement opportunities by preference and reserved groups. The study therefore recommended that the relevant government agencies make resources available, pay attention to procurement ethical issues, make people living with disabilities aware of public procurement opportunities and use technology in the running of procurement function so that more disadvantaged people get access public procurement opportunities (Wazir \& Achuora, 2020).

\section{Research Methodology}

The objective of this research was to examine how Ethical Practices influenced the uptake of AGPO initiative by the youth in Isiolo County in Kenya. The ethical parameters of Professional Code of Conduct, Objective Procurement Evaluation Criteria and Public Procurement Regulatory Compliance were used to measure the degree of relationship and association between the variables. The use of descriptive research design, where relevant and precise information concerning the current status of 
a problem of youth access to the AGPO initiative and the drawing of valid general conclusions from the facts established was found appropriate according to Kothari (2009) who postulates that this design is appropriate for establishing causal relationships with a set of data.

The study population which of the youth from Isiolo County was drawn from the Seven(7) SubCounties, namely Isiolo North, Isiolo, Garbatulla, Merti, Oidolinro, Isiolo Central and Bullapesa. They constituted 55 youth from Isiolo County that had congregated at the Kenya School of Government, Embu to undertake a capacity building programme and who by their demographic disposition constituted a significant bracket of the beneficiaries of the AGPO initiative alongside women and PWDs.

The study tool of data collection was the self-administered questionnaires that was designed in a format, sequence and wording with the inclusion of classification, behavioural, knowledge and perception questions according to Bulmer, (2004). The questionnaire was deemed appropriate since the respondents being youth were literate and capable of reading and interpreting the research questions as raised in the tool to provide valid responses. The tool was also to ensure reliability, validity and sustained engagement of the respondents on matters influencing their uptake of AGPO in the research data collection process. The questionnaire had closed-ended questions that made use of a five-point Likert scale where respondents were required to fill according to their level of agreement with the statements. This was to simplify the comprehension and response to the statements.

Descriptive statistics in the form of frequencies and percentages were used to analyze the data used to deduce how the various ethical influencers affected the uptake of AGPO by the youth in the County. This is an appropriate method which according to Mugenda and Mugenda, (2013) provides concise data descriptions and analysis for ease of interpretation. The Pearson correlation coefficient was used to measure the strength and direction of the relationship between the uptake of AGPO by youth and the ethical influencers. According to Freedman, Pisani and Purves, (2007) this ccorrelation coefficient technique allows the researchers to analyze the degree and direction of the relationship between the dependent variable of the uptake of AGPO and the independent parameters of Ethical Practices in Procurement. The use of scatter plots to demonstrate the degree of the relationship between the variables on a graphical scale provided ease of interpretation by analysts.

\section{Operationalization of the Study Variables}

The responses in the questionnaire were rated on a scale of 1-5, where 1 represented strongly disagree and 5, strongly agree. They were arrived at based on the following parameters: 
Table 1. Operationalization of the study variables

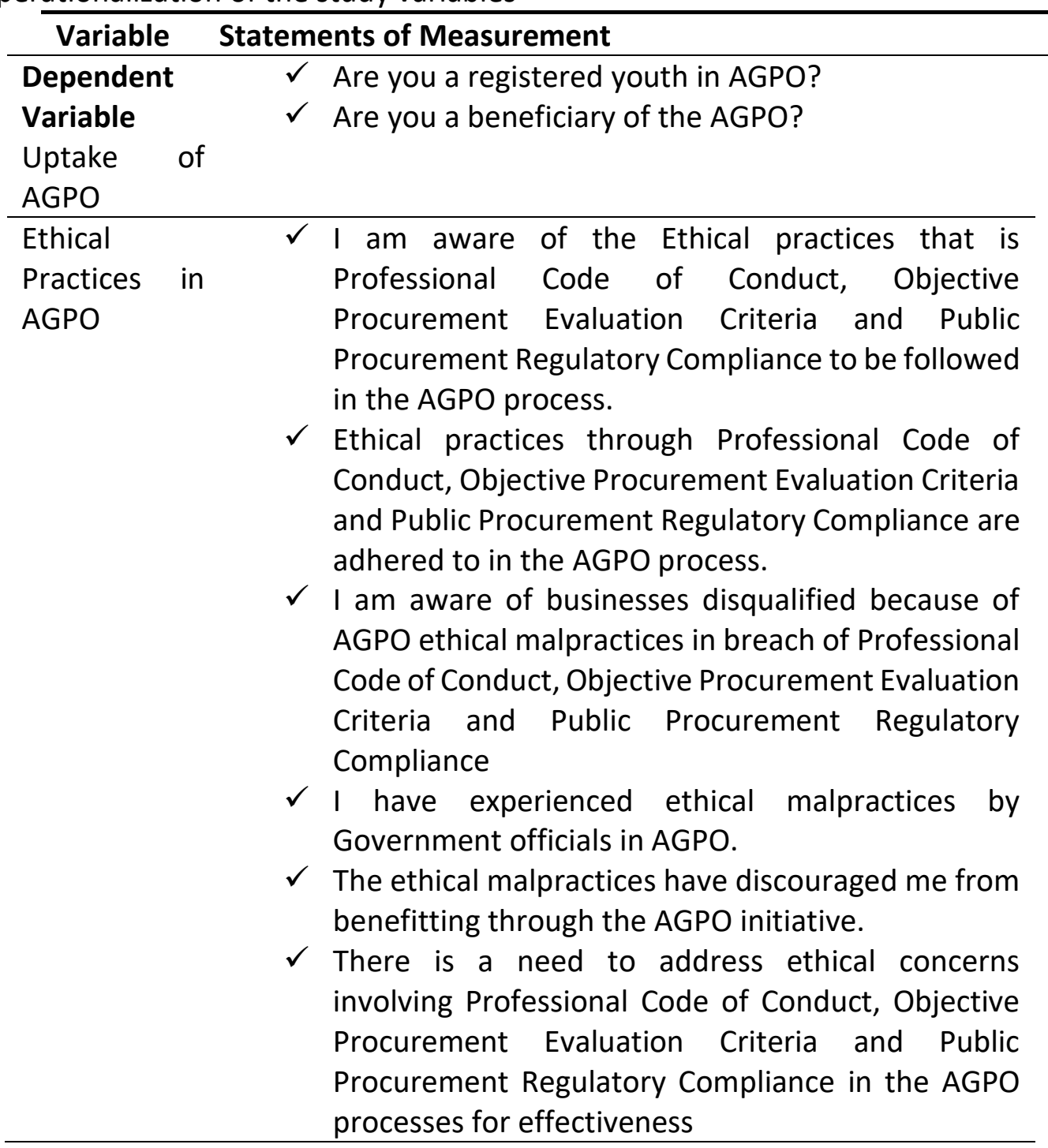

(Source: Authors, 2019)

\section{Research Findings and Discussions}

This section reports the findings of the study and highlights the respondents' response rate, the respondents' demography, descriptive analysis of the study variable using proportions and culminates with the inferential statistics of the study variable using the Pearson's correlation coefficient $r$.

Table 2. Response Rate

\begin{tabular}{llll}
\hline Item & $\begin{array}{l}\text { Administered } \\
\text { Questionnaires }\end{array}$ & $\begin{array}{l}\text { Returned } \\
\text { Questionnaires }\end{array}$ & $\begin{array}{l}\text { Percentage } \\
\text { Remaining }\end{array}$ \\
\hline Respondents & 55 & 55 & $100 \%$ \\
\hline
\end{tabular}

(Source: Authors, 2021) 
INTERNATIONAL JOURNAL OF ACADEMIC RESEARCH IN ACCOUNTING, FINANCE AND

\section{MANAGEMENT SCIENCES}

Vol. 11, No. 1, 2021, E-ISSN: 2225-8329 (c) 2021 HRMARS

From Table 2, it is noted that all the administered questionnaires were filled by respondents and collected for coding and further analysis by the researchers.

\section{Respondents Demography}

Respondents Gender

From Table 3 sixty-seven percent (67\%) of the respondents were male and thirty-three percent (33\%) were female. This is in line with the Kenya Bureau of Statistics Economic Survey (KNBS, 2020) report on enterprises by gender which indicates that men still occupy a significant portion (over $60 \%$ ) of the formal Small and Medium Size businesses in Kenya.

Table 3. Gender of Respondents

( $N=55)$

\begin{tabular}{rrl}
\hline Gender & $n$ & $\%$ \\
\hline Male 37 & 67.0 \\
Female 18 & 33.0 \\
N 55 & 100.0 \\
\hline
\end{tabular}

(Source: Survey Data, 2021)

\section{Age of Respondents}

From Table 4 seventy-three percent (73\%) of the respondents were between 20-29 years and twenty-seven percent (27\%) were between 30-39 years. This therefore indicates that the respondents from the County were youth. This is because the Constitution of Kenya (COK, 2010) defines a youth as a person aged between eighteen (18) years and thirty-four (34) years while under the African Youth Charter, a youth is a person between fifteen (15) years and thirty-five (35) years.

Table 4. Age of Respondents

$(\mathrm{N}=55)$

\begin{tabular}{rll}
\hline Age & $n$ & $\%$ \\
\hline $20-29$ years & 40 & 73.0 \\
$30-39$ years & 15 & 27.0 \\
$\mathrm{~N}$ & 55 & 100.0 \\
\hline
\end{tabular}

(Source: Survey Data, 2021)

\section{Level of Education}

From Table 5 sixteen percent (16\%) has KCPE, twenty-nine percent (29\%) had KCSE, twentyone percent (21\%) had Certificate, twenty-one percent (21\%) had Diploma and eleven percent (11\%) had a Degree.

This confirms that majority of the respondents have at least the minimum basic education needed to start off a business and have it registered with the AGPO programme. 
Table 5. Level of Education

( $N=55)$

\begin{tabular}{rll}
\hline Level of Education & $\boldsymbol{N}$ & \% \\
\hline KCPE & 9 & 16.0 \\
KCSE & 16 & 29.0 \\
Certificate & 12 & 21.0 \\
Diploma & 12 & 21.0 \\
Degree & 6 & 11.0 \\
$\mathrm{~N}$ & 55 & 100.0 \\
\hline
\end{tabular}

(Source: Survey Data, 2021)

\section{Respondents' Sub-County}

From Table 6 eighteen percent (18\%) were from Isiolo North, fifty-three percent (53\%) from Isiolo, eleven percent (11\%) were from Garbatulla, nine percent (9\%) were from Merti, two percent (2\%) from Oidolinro, four percent (4\%) from Isiolo Central and four percent (4\%) from Bullapesa.

Table 6. Respondents Sub-County

\begin{tabular}{cll}
\hline Sub -County & $\boldsymbol{n}$ & \% \\
\hline Isiolo North & 10 & 18.0 \\
Isiolo & 29 & 53.0 \\
Garbatulla & 6 & 11.0 \\
Merti & 5 & 9.0 \\
Oidolinro & 1 & 2.0 \\
Isiolo central & 2 & 4.0 \\
Bullapesa & 2 & 4.0 \\
N & 55 & 100.0 \\
\hline
\end{tabular}

(Source: Survey Data, 2021)

The proportion of respondents who own a Businesses.

From Table 7 forty-four percent (44\%) of the respondents owned some form of business while fifty-six percent (56\%) did not own a business.

Table 7. Respondents who own a Businesses.

( $\mathbf{N}=\mathbf{5 5})$

\begin{tabular}{cll}
\hline Response & $\boldsymbol{n}$ & $\boldsymbol{\%}$ \\
\hline Yes & 24 & 44.0 \\
No & 31 & 56.0 \\
$\mathrm{~N}$ & 55 & 100.0 \\
\hline
\end{tabular}

(Source: Survey Data, 2021)

\section{Respondents Business Ownership}

From Table 8 and Figure 3, sixty-two percent (62\%) has a sole proprietorship, twenty-seven percent (27\%) had partnerships and eleven percent $(11 \%)$ had limited companies. 
INTERNATIONAL JOURNAL OF ACADEMIC RESEARCH IN ACCOUNTING, FINANCE AND MANAGEMENT SCIENCES

Vol. 11, No. 1, 2021, E-ISSN: 2225-8329 @ 2021 HRMARS

Table 8. Business Ownership

$(\mathrm{N}=55)$

\begin{tabular}{rll}
\hline Type of Business & $\boldsymbol{n}$ & \% \\
\hline Sole proprietorship & 16 & 62.0 \\
Partnership & 7 & 27.0 \\
Limited Company & 3 & 11.0 \\
$\mathrm{~N}$ & 26 & 100.0 \\
\hline
\end{tabular}

(Source: Survey Data, 2021)

Business Ownership

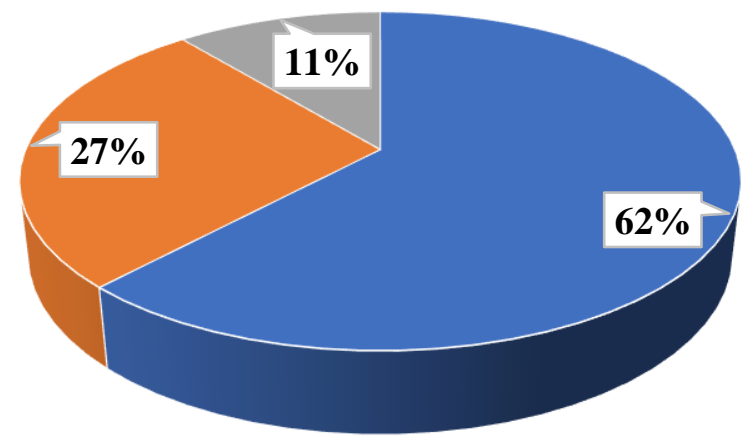

- Sole proprietorship $\quad$ "Partnership $\quad$ - Limited Company

Figure 3. Business Ownership

(Source: Survey Data, 2021)

Cross tabulation of business ownership and with the type of Business

From Table 9 sixty-seven percent (67\%) did own a business and were sole proprietors. Twenty-one percent (21\%) did own a business but were in partnerships, whilst twelve percent (12\%) did own a business but were in Limited Companies. Twenty-nine percent (29\%) did not own a business but were in partnerships. 
INTERNATIONAL JOURNAL OF ACADEMIC RESEARCH IN ACCOUNTING, FINANCE AND

MANAGEMENT SCIENCES

Vol. 11, No. 1, 2021, E-ISSN: 2225-8329 @ 2021 HRMARS

Table 9. Cross Tabulation of Business ownership and Type of Business

\begin{tabular}{|c|c|c|c|c|c|c|}
\hline & & & What is the typ & of Business & nership & $\%$ \\
\hline & & & $\begin{array}{l}\text { Sole } \\
\text { proprietorship }\end{array}$ & Partnership & $\begin{array}{l}\text { Limited } \\
\text { company }\end{array}$ & \\
\hline & & $N$ & 16 & 5 & 3 & 24 \\
\hline & Yoc & Do you own a business & $67 \%$ & $21.0 \%$ & $12.0 \%$ & $100.0 \%$ \\
\hline Do you & res & $\begin{array}{l}\text { What is the type of } \\
\text { Business Ownership }\end{array}$ & $100.0 \%$ & $71.0 \%$ & $100.0 \%$ & $92.3 \%$ \\
\hline OWn a & & $N$ & 0 & 2 & 0 & 2 \\
\hline oustress & $\mathrm{No}$ & Do you own a business & $0.0 \%$ & $100.0 \%$ & $0.0 \%$ & $100.0 \%$ \\
\hline & INO & $\begin{array}{l}\text { What is the type of } \\
\text { Business Ownership }\end{array}$ & $0.0 \%$ & $29.0 \%$ & $0.0 \%$ & $8.0 \%$ \\
\hline & & $N$ & 16 & 7 & 3 & 26 \\
\hline$\%$ & & Do you own a business & $62.0 \%$ & $27.0 \%$ & $11.0 \%$ & $100.0 \%$ \\
\hline 70 & & $\begin{array}{l}\text { What is the type of } \\
\text { Business Ownership }\end{array}$ & $100.0 \%$ & $100.0 \%$ & $100.0 \%$ & $100.0 \%$ \\
\hline
\end{tabular}

(Source: Survey Data, 2019)

Findings and Discussions on how Ethical Practices influence the uptake of AGPO by the youth in Isiolo County.

From Table 10 eighty-two percent (82\%) agreed that they were aware of ethical practices to be followed in the AGPO process. This therefore indicates that the youth in the County were fully aware of the existing ethical expectations and practices both by potential beneficiaries and agents of the AGPO initiative. This consciousness is critical as it provides a basis of moral judgement in the event of unethical practices. Hannah and Jaimie, (2020) in their analysis on Consumerism Consciousness argue that by supporting ethically sourced businesses based on ethical awareness, consumers can help to protect the ethical environment while simultaneously avoiding goods and services that are exploitative. This, accordingly, would be a way of ensuring that a product or service is produced ethically is through fair business practices.

The findings also show that eighty-one percent (81\%) of the respondents agreed that ethical practices are adhered to in the AGPO process. It is therefore conclusive that both agents and beneficiaries adhered to the code of conduct, objective procurement evaluation criteria and complied with the public procurement laws and regulations. Similarly, fifty-one percent (51\%) of the respondents were aware of businesses being disqualified because of AGPO ethical malpractices. This level of consciousness of punishment out of breaching ethical practices as argued in the Teleological Ethical Theories is a potent deterrent to unethical practices in the administration of the AGPO program and would be of interest to policy makers. This could further explain the findings on respondents' having experience on ethical malpractices by Government officials in the AGPO program of which thirty-five percent (35\%) disagreed and thirty-four percent (34\%) agreed, whilst twenty-eight percent (28\%) did not know.

Further findings indicate that fifty-nine percent (59\%) of the respondents disagreed that ethical malpractices had discouraged them from benefitting through the AGPO initiative. This is an 
INTERNATIONAL JOURNAL OF ACADEMIC RESEARCH IN ACCOUNTING, FINANCE AND MANAGEMENT SCIENCES

Vol. 11, No. 1, 2021, E-ISSN: 2225-8329 @ 2021 HRMARS

indication that ethical practices had not hindered the youth participation in the AGPO activities which illustrates perceived fair play in the program processes. However, ninety-two percent (92\%) agreed that there is need to address ethical concerns in the AGPO processes for effectiveness, and this is paradoxical based on the earlier findings in which there was perceived fair play in the process.

It could be explained by the words of Donald Menzel, (2005) who argues that some contemplated ethical malpractices are better flagged out in time to ensure consistent application of business ethical practices.

Table 10. Descriptive Statistics of the Study Variable, Ethical Practices

$(\mathrm{N}=55)$

\begin{tabular}{|c|c|c|c|c|c|c|}
\hline \multirow[t]{2}{*}{ Parameter } & $\begin{array}{l}\text { Strongly } \\
\text { Disagree }\end{array}$ & Disagree & $\begin{array}{l}\text { Don't } \\
\text { Know }\end{array}$ & Agree & $\begin{array}{l}\text { Strongly } \\
\text { Agree }\end{array}$ & Mean \\
\hline & \multicolumn{6}{|l|}{ Percentage } \\
\hline \multirow{2}{*}{\multicolumn{7}{|c|}{$\begin{array}{l}\text { i. I am aware that the ethical } \\
\text { practices which are } \\
\begin{array}{l}\text { Professional Code of } \\
\text { Conduct, Objective } \\
\text { Procurement Evaluation } 2.0 \\
\text { Criteria and Public } \\
\text { Procurement Regulatory } \\
\text { Compliance need to be } \\
\text { followed in the AGPO } \\
\text { process }\end{array}\end{array}$}} \\
\hline & & & & & & \\
\hline \multicolumn{7}{|l|}{$\begin{array}{l}\text { ii. Ethical practices, that is } \\
\text { Professional Code of } \\
\text { Conduct, Objective } \\
\text { Procurement Evaluation }\end{array}$} \\
\hline $\begin{array}{l}\text { Criteria and Public } \\
\text { Procurement Regulatory } \\
\text { Compliance are adhered to } \\
\text { by agents in the AGPO } \\
\text { process in Isiolo County }\end{array}$ & 4.0 & 8.0 & 6.0 & 62.0 & 19.0 & 3.01 \\
\hline $\begin{array}{l}\text { ii. I am aware of businesses } \\
\text { disqualified because of } \\
\text { AGPO ethical malpractices }\end{array}$ & 2.0 & 16.0 & 31.0 & 41.0 & 10.0 & 2.65 \\
\hline $\begin{array}{l}\text { v. I have experienced ethical } \\
\text { malpractices by } \\
\text { Government officials in } \\
\text { AGPO }\end{array}$ & 9.0 & 29.0 & 28.0 & 28.0 & 6.0 & 2.90 \\
\hline $\begin{array}{l}\text { v. The ethical malpractices } \\
\text { have discouraged me from } \\
\text { benefitting through the } \\
\text { AGPO initiative }\end{array}$ & 21.0 & 38.0 & 4.0 & 31.0 & 6.0 & 2.65 \\
\hline
\end{tabular}


INTERNATIONAL JOURNAL OF ACADEMIC RESEARCH IN ACCOUNTING, FINANCE AND MANAGEMENT SCIENCES

Vol. 11, No. 1, 2021, E-ISSN: 2225-8329 @ 2021 HRMARS

\begin{tabular}{lllllll}
\hline Parameter & $\begin{array}{l}\text { Strongly } \\
\text { Disagree }\end{array}$ & Disagree & $\begin{array}{l}\text { Don't } \\
\text { Know }\end{array}$ & Agree & $\begin{array}{l}\text { Strongly } \\
\text { Agree }\end{array}$ & Mean \\
\cline { 2 - 6 } & Percentage & & & \\
\hline $\begin{array}{l}\text { vi. There is need to address } \\
\text { ethical concerns in the } 2.0\end{array}$ & 2.0 & 4.0 & 64.0 & 28.0 & 4.14 \\
$\begin{array}{l}\text { AGPO processes for } \\
\text { effectiveness }\end{array}$ & & & & & \\
\hline
\end{tabular}

(Source: Survey Data, 2019)

From Figure 4 on Mean of Parameter scores, it can be concluded that the response with the highest mean of Strongly Agree is (iv) whereby the respondents indicated that there is need to address ethical concerns in the AGPO processes for effectiveness of the program. This is therefore a major ethical concern worth policy intervention. The level of awareness of the ethical practices and that they are complied with in the AGPO administration as per parameter (i) and (ii) is an indication of understanding of ethical concerns by the respondents and hence the youth at large.

\section{Likert Scale (1-5)}

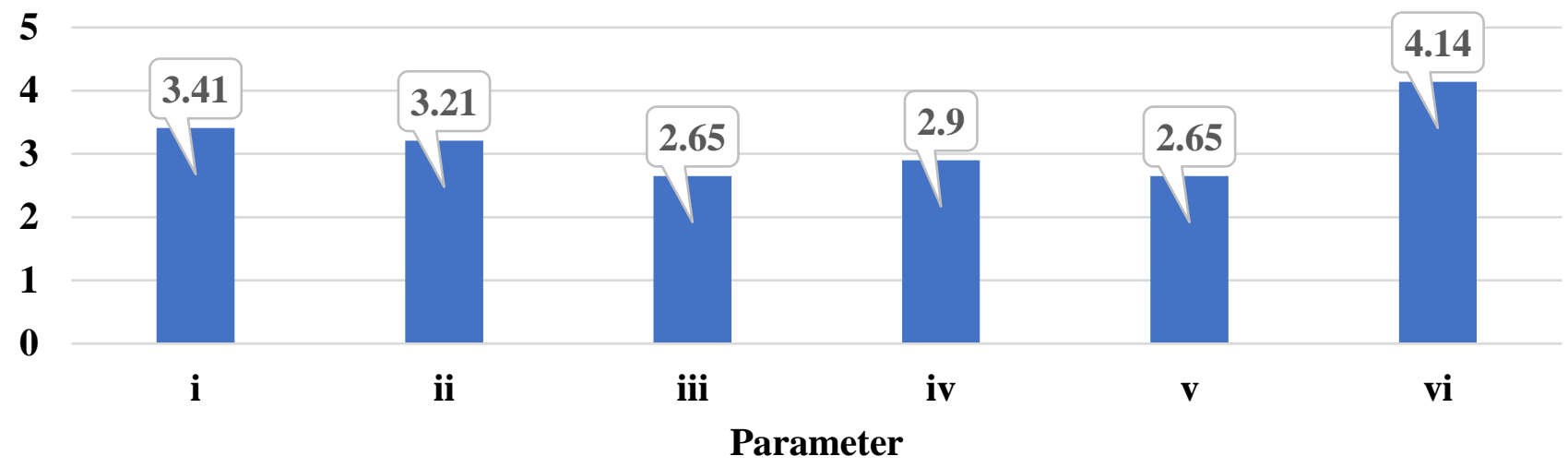

Figure 4. Mean of Parameters

(Source: Survey Data, 2019)

Inferential Statistics of the Study variable, Ethical Practices on Uptake of AGPO

Based on the interpretation of the correlation coefficients of the study variables, of $\mathrm{H}_{\mathrm{oi}}: \rho_{i}=0$ versus $\mathrm{H}_{\mathrm{oi}}: \rho_{i} \neq 0(\mathrm{i}=1)$, therefore, if the hypothesis is rejected then the independent variable $\mathrm{X}_{\mathrm{i}}$ had a statistically significant relationship or association with the dependent variable $Y$ (Chen \& Popovich, 2002). The decision to reject or fail to reject the Null Hypothesis was therefore based on the statistical significance of the correlation coefficient $(p \leq 0.05)$.

Therefore, the independent variable Ethical Practices had a statistically significant moderate positive correlation with the dependent variable Uptake of AGPO $r(51)=.562 p<.05$ hence we REJECT the Null Hypothesis $\mathrm{H}_{01}$ : which was that Ethical Practices do not have a statistically significant relationship with the uptake of AGPO by the youth in Isiolo County. 
INTERNATIONAL JOURNAL OF ACADEMIC RESEARCH IN ACCOUNTING, FINANCE AND MANAGEMENT SCIENCES

Vol. 11, No. 1, 2021, E-ISSN: 2225-8329 @ 2021 HRMARS

Table 11. Correlation Coefficients between Ethical Practices and the uptake of AGPO $(\mathrm{N}=55)$

Determinant of AGPO $\left(\mathrm{X}_{\mathrm{i}}\right)$

Uptake of AGPO (Y)

Ethical Practices

Pearson Correlation

$.562 *$

Sig. (2-tailed)

.041

$\mathrm{N}$

55

*. Correlation is significant at the 0.05 level (2-tailed).

(Source: Survey Data, 2021)

These results are displayed in a scatter plot of the correlation coefficient of the variables as shown in Figure 5 and the randomness suggest no clear relationship between ethical practices and the uptake of AGPO by youth in Isiolo County.

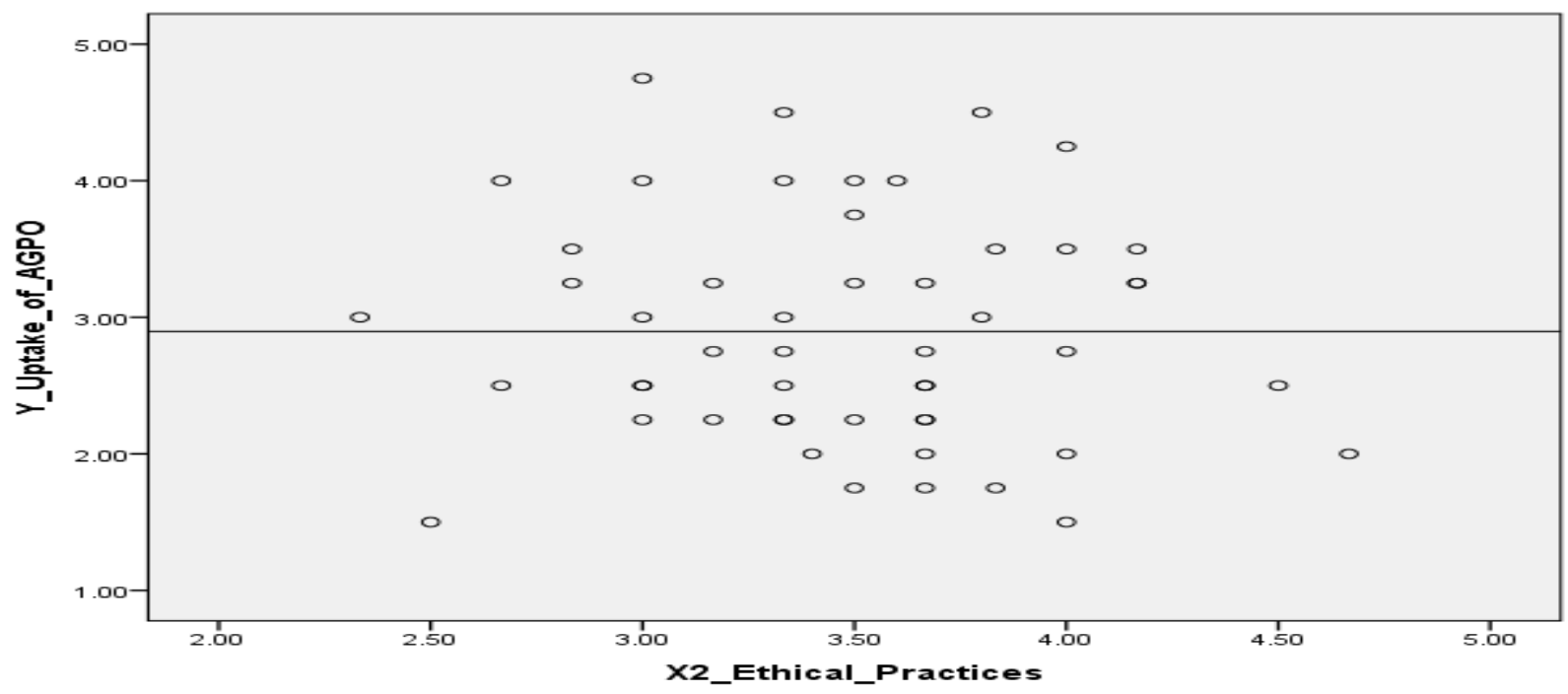

Figure 5. Scatter Plot

(Source: Authors. 2021)

\section{Conclusion}

The study sought to establish how Ethical Practices influences the uptake of AGPO by the youth in Isiolo County. This was based on the ethical practice influencers of Professional Code of Conduct, Objective Procurement Evaluation Criteria and Public Procurement Regulatory Compliance.

Based on the findings, the study concluded that Ethical Practices had a moderate positive correlation with the uptake of AGPO. There was therefore hardly any significant relationship between the ethical practices and the AGPO program uptake. It emerged that despite the youth and agents being aware of the malpractices that were ongoing, their consequences and effects, these had not deterred the youth and these agents from engaging in AGPO program. It can therefore be deduced that ethical practices remained uninfluenced by the existing regulations, code of conduct and existing evaluation criteria.

This could be explained by the works of Gilman, (2005) who argues that codes most often fail to influence decisions because they raise unrealistic expectations. He says that though paradoxical, codes succeed because of their successes and those successes must be targeted and reasonable. If 
INTERNATIONAL JOURNAL OF ACADEMIC RESEARCH IN ACCOUNTING, FINANCE AND

MANAGEMENT SCIENCES

Vol. 11, No. 1, 2021, E-ISSN: 2225-8329 @ 2021 HRMARS

failures outnumber successes, there tends to be a spiraling effect where more and more violations seem to occur. He observes that Philippines had experienced this spiral at least twice in the last decade and the code and the systems designed to implement it are deserted as one more demonstration of a countries failures. In some cases, according to Menzel, (2009) codes will also fail because they try to control too much.

In an interesting study of the New York City police department, he says, the ethics regime was criticized because it made it impossible for the police to do their work. There were so many forms to fill out, regulations to follow, questions that needed to be asked that the police, it was argued, could not address crime. Considering that in the AGPO program, the expectations before registration alongside the compliance expectations and regulatory framework one then wonders if not this could be the cause of the statistical indifference as communicated by the findings in this study.

\section{Recommendations}

From these findings, there is apparent need for a study to establish if the existing ethical framework governing the AGPO program is appropriate in enhancing the uptake of the initiative. This could be through comparative studies of similar frameworks in other jurisdictions, their types of frameworks with an assessment of the effectiveness in influencing the uptake of such preference procurement processes. This would in turn help guide policy revision in Kenya on AGPO administration to enhance the realization of its objectives.

\section{References}

Access to Government Procurement Opportunities (AGPO). (2015). Access to Government

Procurement Opportunities (AGPO). Retrieved on March 17, 2015, from Access to Government Procurement Opportunities (AGPO): www.agpo.go.ke

AGPO. (2017). Retrieved from Access to Government Procurement Opportunities: http://agpo.go.ke/ www.ppoa.go.ke. (2017, 09 18). Retrieved from Public Procurement Code of Ethics for Procuring Entities - PPOA: www.ppoa.go.ke/.../Public Procurement Code of Ethics for Procuring Entities.pdf

American Psychological Association. (2020). Publication manual of the American Psychological Association (7th ed.). https://doi.org/10.1037/0000165-000

Arrowsmith, S. (2010). Public Procurement Regulation: An introduction, The Public Procurement Research Group. University of Nottingham, United Kingdom

Callaghan, C. W. (2009) A Dissertation Submitted to the Faculty Of Commerce, Law and

Management, University of the Witwatersrand, Johannesburg, in Fulfilment of the Requirements for the Degree of Master of Commerce. Unpublished

Camp, W. G. (2001). Formulating and Evaluating Theoretical Frameworks for Career and

Technical Education Research. Journal of Vocational Educational Research, 26(1), 27-39

Chen, P. Y., \& Popovich, P. M. (2002). Correlation: Parametric and nonparametric measures. Thousand Oaks, CA: Sage Publications, London.

Harris, L., Rae, A., \& Misner, I. (2012) Punching above their weight: the changing role of networking in SMEs. Journal of Small Business and Enterprise Development. Emerald Group Publishing Limited.

Donald, C. M. (2009). Ethics Moments in Government: Cases and Controversies(1st Edition) ASPA Series in Public Administration and Publications 
INTERNATIONAL JOURNAL OF ACADEMIC RESEARCH IN ACCOUNTING, FINANCE AND

MANAGEMENT SCIENCES

Vol. 11, No. 1, 2021, E-ISSN: 2225-8329 @ 2021 HRMARS

Eyaa, S., Oluka, P. N. (2011). Explaining non-compliance in public procurement in Uganda. International Journal of Business and Social Science. 2(11):35-45.

Gatere, B. C., \& Shale, N. I. (2014). Challenges affecting the implementation of access to Government procurement opportunities for special interest groups in Kenya: A case of Nairobi County. International Journal of Social Sciences and Entrepreneurship, 1 (12),831-847

Gilman, S. C. (2005) Ethics Codes and Codes of Conduct as Tools for Promoting an Ethical and Professional Public Service: Comparative Successes and Lessons. The PREM, the World Bank, Washington DC.

Government of Kenya (GoK). (2005). The Public Procurement and Disposal Act, No. 3 of 2005.Nairobi: Government Printers

Government of Kenya. (2015). The Public Procurement and Asset Disposal Act, 2015. Nairobi: Government Printer.

Government of Kenya. (2013). Public Procurement and Disposal (Preference and Reservations (Amendment No.2) Regulations, 2013. Nairobi: Government Printer.

Government of Kenya (2013). The Public Procurement and Disposal (County Government) Regulations. Nairobi. Government Printers.

Guba, E. G., \& Lincoln, Y. S. (1989). Fourth Generation Evaluation. Sage Publications, London.

Hivos East Africa. (2018). Impact of Kenya' Access to Government Procurement Opportunities (AGPO) law on youth women and persons with disabilities. http: www.east-africa.hivos.org

International Labour Organization. (2009). Inclusion of People with Disabilities in Kenya. Nairobi: International Labour Organization.

International Trade Centre, (2010). Understanding the Corporate Environment: MLS-SCM Course Book Module 1, United Kingdom: International Trade Centre.

Jackson, S. L. (2009). Research Methods and Statistics: A Critical Thinking Approach 3rd edition. Belmont, CA: Wadsworth.

Kenneth, R. A. (1989). Ethics in Practice: Harvard Business Review pp. 99-104, Volume 67

Kothari. (2009). Quantitative Techniques(3rd Revised Edition). Nairobi: Vikas Publishing House PVT Ltd.

Kenya National Bureau of Statistics, 2010 (KNBS). (2010). The 2009 Kenya Population and Housing Census. Nairobi: Population Reference Bureau.

Kenya Law. (2017, 09 18). Retrieved from Laws of Kenya: http://kenyalaw.org

Kuratko, D. F., \& Hodgetts, R. M. (2007) Entrepreneurship in the New Millennium. Cengage Learning India private limited.

Lagat, M. K., Namusonge, G., \& Berut, Z. (2016). Factors Affecting Youth, Women and Persons with Disabilities in Accessing Procurement Opportunities in Trans Nzoia County Government. International Journal of Recent Research in Commerce Economics and Management (IJRRCEM). $3,(2)(42-66)$.

Lumpkin, R. D., \& Dess, G. G. (1996) Clarifying the Entrepreneurial Orientation Construct and Linking it to Firm Performance, Academy of Management Review.21,135-172.

Mahmood, R., \& Hanafi, N. (2013) Entrepreneurial Orientation and Business Performance of Women Owned Small and Medium Enterprises in Malaysia. Competitive Advantage as a Mediator. International Journal of Business and Social Sciences. Vol.4.No.1

Mahmood, M. (2010) 'British Must Move Fast to Profit on the Trade Front'. The Times 18th January 2005 
INTERNATIONAL JOURNAL OF ACADEMIC RESEARCH IN ACCOUNTING, FINANCE AND

MANAGEMENT SCIENCES

Vol. 11, No. 1, 2021, E-ISSN: 2225-8329 @ 2021 HRMARS

McCrudden, C. (2004). Using Public Procurement to Achieve Social Outcomes. Natural resources Forum 28 (pp. 257-267). Blackwell Publishing

Ministry of Youth Affairs. (2006). Kenya National Youth Policy. Nairobi: Ministry of Youth A_airs.NGEC. (2017, August 09). Retrieved from National Gender and Equality Commission: http://www.ngeckenya.org/

Mugenda, A., and Mugenda, O. (2013). Research methods: Quantitative and qualitative approaches. Nairobi: ACTS PressMuraguri, J., (2013) Implementation of the youth preference and reservation policy in Public Procurement. The case of state-owned enterprises in Nairobi. The University of Nairobi. Unpublished.

Mukabi, F. K., Kangethe, A., and Simiyu, D. (2020). Nexus between the Access to Government Procurement Opportunities Initiative's Legal and Regulatory Framework with Its Uptake by Youth in Isiolo County, Kenya, The International Journal of Business \& Management 8(4) DOI: 10.24940/theijbm/2020/v8/i4/BM2004-029

Mwangi, P. N. (2017). Determinants of compliance with access to Government procurement opportunities regulations for special groups by public universities in Kenya. The University of Nairobi. Unpublished.

Ndolo, J., and Njagi, E. (2014) Role of Ethics in Procurement Process Effectiveness in the Water Sector in Kenya: A Case Study of EWASCO, Embu County. International Journal for Supply Chain Management, Vol. 3(3) (128-133).

Nduta, C., Ayuma, C., Langat, B., \& Yego, S (2015). Factors Affecting Youth Participation in Public Procurement in Kenya: A Survey of Youth Enterprises in Mombasa County. The International Journal of Business \& Management. 3(9)2321 -8916.

Ngugi, J., \& Mugo, H. (2011). Internal factors affecting procurement process of supplies in public sectors. Journal of Public Procurement, 1.

Nkonge, B. K. (2013). Challenges faced by Small and Medium Enterprise Suppliers when bidding for tenders. A case of Thika District. International Journal of Academic Research in Business and Social Sciences, 3(12)194

Obiri, L. (2016). Consultancy Onthe Assessment Of The Uptake Of 30\% Public Procurement Business Opportunities For Women, Youth And Pesrons Withdisability At The County Level And Availability Of Business Development Services. Nairobi: Unwomen.

Odoyo, F., \& Lipindi, B. (2012) Compliance of Public Procuring Entities in Dar Es Salaam. Kampala International University.

PPOA. (2016). Kenya Power and Lighting Company Ltd Procurement Review Report. Retrieved from: http://www.ppoa.go.ke/images/downloads/review-reports/ SUMMARY\%200F\%20REVIEW_REPORT-\%20KPLC.pdf

Public Procurement and Disposal Act. (2005). Kenya Gazette Supplement No. 77(Acts No. 3)

Public Procurement and Disposal General Manual. (2009). Public Procurement Oversight Authority. Public Procurement and Disposal Regulations (2013). Public Procurement and Disposal Regulations (2013).

Public Procurement Oversight Authority. (2007). Assessment of the Procurement System in

Kenya Public Procurement Oversight Authority. Retrieved from http://www.oecd.org/devt/effectiveness/41583965.pdf

Republic of Kenya. (2005) "Public Procurement and Disposal Act and Regulations" Nairobi: Government Printers. 
INTERNATIONAL JOURNAL OF ACADEMIC RESEARCH IN ACCOUNTING, FINANCE AND

MANAGEMENT SCIENCES

Vol. 11, No. 1, 2021, E-ISSN: 2225-8329 @ 2021 HRMARS

Republic of Kenya. (2003) Kenya Vision 2030, A Globally Competitive and prosperous Kenya.

Republic of Kenya. (2013) Economic recovery for wealth and employment creation (2003-200

7) Nairobi: Government Printers

Republic of Kenya. (2013). Economic recovery for wealth and employment creation (20032007) Nairobi: Government Printers

Roodhooft, F., \& Abbeele, A. V. D. (2006). Public procurement of consulting services

Evidence and comparison with private companies. International Journal of Public Sector Management, 19(5) 490-512.

Scott, R. (2004) 'China's legal framework for public procurement' . Journal of Public Procurement Vol.3 (3) 370-388

Simayi, S. (2005). Examination of Preferential Procurement, Enterprise Development and Corporate Social Investment with regards to the BEE draft codes of good practice Unpublished MBA Research Report, UCT Graduate School of Business.

Sutinen, J. G., \& Kuperan, K. (2009). A socio-economic theory of regulatory compliance. International Journal of Social Economics, 26(1/2/3) 174-193.

The Constitution of Kenya, 2010. (2010). Nairobi: The Government Printer, Nairobi

United Nations. (2017, 09 18). Retrieved from United Nations Global Market Place: https://www.ungm.org/Areas/Public/pph/index.html

UNCITRAL. (2014). UNCITRAL Model Law on Public Procurement. Vienna, Austria: United Nations.

Wanderi, C. (2014). Kenya: New Public Procurement Rules Good for Business. The African Executive.

Walker, H., \& Brammer, S. (2009). Sustainable Procurement in the UK Public Sector. Supply Chain Management: An International Journal, 14 (2): 128-37.

Wazir, A. A., \& Achuora, J. (2020). Factors affecting access to government procurement opportunities (AGPO) by preference and reserved groups in Nairobi City County, Kenya. The Strategic Journal of Business \& Change Management, 7(3), $240-252$.

Wleh, N. P. (2013). Factors Influencing Youth Access To Public Procurement Opportunities In The Government Ministries In Kenya. UON. Unpublished. 